\title{
THE HIGH KARAKALPAKS AND THEIR CUSTOMS
}

\section{Amangul Ansatbaevna Prekeeva}

Lecturer, Department of Social And Humanitarian Subject, Nukus Branch Of The Uzbek State Institute Of Arts And Culture, Uzbekistan

\section{ABSTRACT}

Karakalpakstan is a sovereign state within the Republic of Uzbekistan. The back of the Republic of Karakalpakstan is the Red Sand Desert in the west, the Ustyurt Plain in the east and the foothills of the Aral Sea in the west of the Amu Darya of the Republic of Uzbekistan. In the Republic of Karakalpakstan, Karakalpak and Uzbek are the official languages.

KEYWORDS: - Uzbekistan, Karakalpakstan, Aral Sea, Amu Darya, Ustyurt, Kipchak, Khorezm, Syrdarya, Kokand, Bukhara, Berdak, Turkic, language, Kenimekh, Navoi.

\section{INTRODUCTION}

The language that the Karakalpaks have been using along the Kubla Aral since ancient times is considered to be the Kipchak dialect of the Turkic languages. They were settled in the eastern and western parts of the Aral Sea as a result of the intermingling of several ethnic groups from the Middle Ages to the Middle Ages.

Due to various reasons for the formation of the Karakalpaks, the Ustyurt and Sarykamys moved to the northwest of Khorezm, along the Uzboy, and some went along the Volga and became part of the Golden Horde.

At the end of the 14 th century and the beginning of the 15th century, the Golden Horde disintegrated into several nations. At the end of the 15 th century, the Karakalpaks, like others, seceded from the Uzbek Khanate. In this period, together with the nogai, it forms a circle. Due to the death of the khan of the Horde Ormanbet, there was a great catastrophe and famine. From there he moved to the Volga Urals and Turkestan, ie to the Syrdarya region. However, due to the attacks of the Dzungars on the Karakalpaks along the Syrdarya in 1723 and 1743, Abylkhairkhan began to return to his homeland. Due to the conquest of the middle reaches of the Syr Darya by the Dzungars, the Karakalpaks are divided into "upper" and "lower". The Upper Karakalpaks were created by the Karakalpaks of the Kokand and Bukhara Khanates at that time, and the Lower Karakalpaks were created by the Amu Darya at the foot of the Aral Sea. Today, the Upper Karakalpaks live in Fergana, 
CURRENT RESEARCH JOURNAL OF PHILOLOGICAL SCIENCES 2(11):

72-79, November 2021

DOI: https://doi.org/10.37547/philological-crjps-02-11-17

ISSN 2767-3758

(C)2021 Master Journals

Crossref do

gil Google

Accepted $25^{\text {th }}$ November, 2021 \& Published $30^{\text {th }}$ November, 2021

Andijan, Namangan, Navoi, Samarkand, Tashkent, Jizzakh, and in the Shymkent region of the Republic of Kazakhstan and in Afghanistan.

The epic "Amangeldi" in the upbringing of our great-grandfather Berdak, an outstanding representative of our classical literature of the XIX century, tells about the noble deeds of the hero Amangeldy, who worked in the Kokand Khanate. At that time there was information about the creation of Karakalpaks in Kokand khanate.

DS Nasyrov's work on the language of the Karakalpaks in the Fergana Valley is described as a "separate conversation." In this work, DS Nasyrov focuses on the phonetics, vocabulary and morphology of the Karakalpak language.

\section{Main PART}

Karakalpaks are considered to be the most active Karakalpaks in the Kenimekh district of Navoi province, which has retained a sense of national identity. Their language has been scientifically studied and it has been scientifically proven that the Karakalpak language is spoken by Kenimekh.

Terms related to customs and traditions:

There are differences between the customs and traditions of the Kenimekh district at weddings and other ceremonies, which they do closely in the Navoi region.

All kinds of customs, traditions, historical epochs appear, and the people who bring them up, keep their minds as the apple of their eye, try to pass it on to future generations. Therefore, we see that the customs and traditions of each nation and people have been preserved for several centuries. As a proof of this, in Kenimekhli Karakalpaks, cradle weddings, tiger weddings, circumcision weddings, simple weddings, the age of the prophet, forty, fifty, sixty, seventy, eighty years, bridesmaids and bridesmaids are now celebrated. Terms related to funerals are also used.

\section{We will consider the following terms:}

Kuda tusti - at the request of the parents and the boyfriend, the boy's elders are asking for the girl. People here call it "kuda tusti". Those who go to the wedding should be eloquent and eloquent. For example: Today I am going to Khozhabek aga's house to get married (Eltai). And in the literary language it is used under the term "marriage".

Irge keriu- after the agreement, the groom's arms and sleeves go to see the man (probably from the meaning of the black house) (Karakalpaks in Zhanakazgan), to get acquainted with the girl's house, to take six or seven pieces of clothing, earrings, rings mark the girl as a bride (Eltai).

In our language, the dialect and its dialects also use the term masculinity, in which the newlyweds go to the matrimonial relationship to get acquainted with each other, but it is a little closer to the meaning of the dialect in the literary language.

Nan sindiriu - after the bride is engaged, the groom goes to the bread-breaker and breaks a pair of loaves. All relatives, young men and women will taste it. Thus their divinity is established. For example: Orazbek aga's cousins come to break bread (Karakalpaks in Zhanakazgan). In the literary language, the tradition of 'breaking bread' encounters more or less semantic differences.

Bir togys-This is the name given to a loaf of bread brought by a well-wisher. One weave is the number of sarpai (one coat, eight garments), in addition to this weave, "Karakalpaks in Zhanakazgan" brings nine layers and half a ripe sheep. For example: Kudalar brought a knot (Sarybel). 
CURRENT RESEARCH JOURNAL OF PHILOLOGICAL SCIENCES 2(11):

72-79, November 2021

DOI: https://doi.org/10.37547/philological-crjps-02-11-17

ISSN 2767-3758

(C2021 Master Journals

Crossref doi

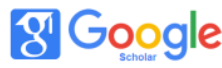

Accepted25 ${ }^{\text {th }}$ November, 2021 \& Published $30^{\text {th }}$ November, 2021

Ush togys - the groom brings three knots when he comes to pick up the girl. One will have nine coats, the other nine will have a two-meter collection, and the third will have nine two-meter dresses.

Traditional terms such as one nine and three nine are not found in the Karakalpak literary language, its Arka and Kubla dialects. In a similar dialect, there was a ritual of "throwing tahiya". Earlier, the girl, who was preparing to become a bride, wore nine dresses at home. One of them had nine crowns. In all nine, he distributed it to the Harris. To my son, such a ceremony was called the "sacrifice".

Bauir kade- cooked lamb's tail fat and liver are pulled in front of the pits. The opposite of this means brotherhood, kinship. In the literary language, the word "liver" is used in the same way in the Karakalpak language.

Kuda is the name given to a horse, which is wrapped in a blanket and pushed with a stick. Also, at this time, the ten-year-old, the old woman died, is wanted. In the literary language, the terms ten dead old women are pronounced and executed in the same way.

Iliu- is a souvenir in which the groom hangs on the doorstep (men's coats for ghosts) and brings material for hanging in the house where the groom was shot (the groom takes the child into a neighboring house). The bridegroom's house is here (Sarybel).

Salgak - this gift is given to the girl's brother-in-law. The noses are now given in cash. Saglak is a combination of the words savga + ilak in terms of structure. In the literary language, it was also called syynak (gift + gift).

Kalta karau kadesi - the groom's sleeves put money in the pocket of the groom on the end of the scarf. He takes it from the girl's sleeves and puts it in the girl's pocket. Although this rule is common in the Karakalpak tradition, there are differences in its implementation.

Kudagay kalta - before going to the girl's house, the guy's house is packed. She puts sweets, cookies, nabat, black tea, green tea, dresses, towels, sleeves on the girl's sleeves, sleeves on the girl's sleeves. In this literary language it is called the divine tradition, and in its implementation there are wigs. As the girl was being escorted, she added two sleeves and a sister.

Tosek orni - is a blanket given to a girl, as she is called. Instead of a bed, the noses gave one weave, that is, a carpet, alasha, felt, palas, a total of nine items, about five or seven items. For example: Six pairs of blankets, four pairs of long blankets, two blankets, six pillows, two neck pillows, everything you need for the house. All the relatives, acquaintances and neighbors who came to the girl's wedding said that they wanted to add her to the world. In this way, everything is put in the girl's box (Sarybel). In the literary language, "girl's gift", "girl's blanket" is given in a figurative sense by the girl's parents and relatives. And in Kenimekh Karakalpaks it is called differently, that is, "bed".

Kudagai Taltak - in the evening, after the girl's farewell, her relatives and parents go to her wedding. In this case, the gods are rewarded. The girl's mother distributes pockets, handkerchiefs and bracelets (Shortepa). This is a collection of traditions of the Karakalpaks here.

Kudagay ashar kade - is a gift from the bride. The person who opens it is given a dress or a handkerchief, and the girl's world is shown to the audience. Although the basket is not so named in the back dialect of our language, it is similar to the tradition of "opening the divine tradition". 
CURRENT RESEARCH JOURNAL OF PHILOLOGICAL SCIENCES 2(11):

72-79, November 2021

DOI: https://doi.org/10.37547/philological-crjps-02-11-17

ISSN 2767-3758

(C)2021 Master Journals

Crossref do

gil Google

Accepted $25^{\text {th }}$ November, 2021 \& Published $30^{\text {th }}$ November, 2021

Greeting - The bride bows as she walks through her husband's door. Traditions are performed with the desire to be beautiful, to have harmony in the household, to be united. He pours oil on the fire, puts salt in it (in the sense of not touching the eyes) and burns it. Ghosts greet and enter the house on the right foot. The bride is put on a curtain and a white scarf (covering her face) is placed on her head. In Karakalpakstan, this tradition is not called "salutation", but in the form of "kelin salem" and "salem bergizi".

The bride's inaugural wedding was held. A poet, a singer, a young man preaches to the bride with a poem (New Karakalpak).

Get along with your neighbors,

Like a bee,

Respect for the elderly

Give me Kishin (New Karakalpak).

The bride is introduced to her parents, brother-inlaw, sister-in-law, neighbors. After that, he spreads a broom on the bride, kneads the flour, kneads the dough, and rolls it with the intention of spinning (nesibeli, spinning like a squirrel) (New Karakalpak).

The traditions of the Kenimek Karakalpaks, such as weddings and meals, have also changed slightly. For example, when they used to give a wedding (whether it was a big wedding or a wedding), relatives and neighbors in the area were informed that they would come to the wedding and give them a present. In the evening there was a shaman, a zhyrau, and the next day there was a game of ylak, but these were requested with the permission of the wedding khan. At that time, a wedding without Karakalpaks was not considered a wedding.

In the evening there will be a youth wedding - a wedding of happiness. All relatives, classmates and neighbors come to him. In a large community, everyone celebrates a happy wedding together. There is a partner in the wedding (the chairman is appointed). The person gives the floor to the wedding guests and wishes them well. In the middle, everyone enters the game, wishes good luck to two-year-olds and greets them (New Karakalpaks). In addition to bridal weddings, circumcision weddings, bag weddings, jubilee weddings, house weddings, and tiger weddings are held.

Assuming that the wedding is preceded by a wedding, that is, a soviet wedding, in the literary language it is called a soviet wedding or a soviet wedding: Today is the wedding of Tursynkul Ata (Kuneabat).

Groom's greetings - the groom's visit to the bride's house, a country tradition in the backyards of Karakalpakstan. Here the groom greets the motherin-law: Bakhytzhan now goes to the "groom's greeting" (Sarybel).

Sunnet toy - is a circumcision in the literary language: "Orazbek aga" now gives a circumcision to his grandson (Sarybel).

Shildehana wedding is a cradle wedding. The cradle is brought by the girl's mother. The child is put to bed by an adult. He puts a shapan, a traditional and a prayer rug on the cradle. In order to make the child dignified, dignified, and religious, he gives a scarf and a dress to the old woman in the cradle (Sarybel).

This is how the mawrit is the prayer or charity that is given after a person's death. I was going to Maurit (Sh. Tepa). The word Maurit in the literary language is iret, pait. Every year he goes to Khiva and Urgench at the same time.

Kudayi - is the alms given after death. As a rule, I was not in my father's god (Sh. Lake). Used in the literary language in the form of alms.

Pakshi is a person who washes the dead, in literary 
CURRENT RESEARCH JOURNAL OF PHILOLOGICAL SCIENCES 2(11):

72-79, November 2021

DOI: https://doi.org/10.37547/philological-crjps-02-11-17

ISSN 2767-3758

(C)2021 Master Journals

Crossref doi

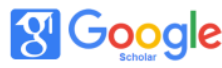

Accepted $25^{\text {th }}$ November, 2021 \& Published $30^{\text {th }}$ November, 2021

language it is called the washing of the dead. The Uzbeks in Gijduvan say murdashay (Shosh tepa): Everyone comes with a pakshi ab.

Twenty is a charity given twenty days after the funeral. There are also ceremonies of the fortieth year.

Negative poetry is called mourning in literary language.

The negative verse is sung at the scene of the tragedy.

The girl led him to the cliff,

He led me to the nest,

We call it farewell,

How do I die? - he laments.

Yamasa, after seven:

The horse wants to flow,

Wearing a gold yoke,

If you want to come,

I miss my brother; - he cries.

It is also called "negative verse" in the Moinak dialect of our language to mourn the death of a person.

Although the term is not used in the literary language, it is used in the gay conversations of our language: it leads to the recitation of negative verses to the place where the dead have died.

The day when the pelvis touches the ground is called the almsgiving (nine hills) in memory of the person 5-6 years after death.

Blue throwing - if a young person close to him dies, he bears a blue good on his head. Then, for nine months, he continued to do so, and then (put the blue).

White pull - a white towel is tied for 35-40 days. For example: The father of the next bride died. I'm also attracted to it. Tamara came to Kanimyk (actress Tamara Doshumova). We didn't go after walking in the white (Shosh hill). Strong-mouthed those who fasted during the month of fasting are said to be strong-mouthed, in literary language: My grandfather's mouth is strong now (Sarybel). "In the period we are talking about, the groups of Karakalpaks in Bukhara (Kenimek, Nurata) and Fergana have fully preserved their national consciousness" (11) - said L.N.Tolstova.

It is said that the Karakalpaks came to the Fergana depression three hundred years ago and settled here on the shores of the Syr Darya (Userbay Mamatov, Tipalik village, Kipchak tribe, 1941). In the past, these places were covered with thick forests. At that time, the khans came here and went out to hunt deer. The Karakalpaks took over the last settlements, planted crops and kept livestock. The khan's troops informed the khan that people had moved to his land. The khan asked them what the people were doing. When the khan found out that they were grazing cattle, he ordered them not to harm them. That's why the people settled here.

He also connects his migration with the events in the epic "Alpamys". The village of Tekelik in the Yazyavan district is divided into three. The first is made by the Kipchaks in the village of Tekelik, the second by the spinner (probably the Sheriushi tribe in the Karakalpaks), and the third by the Naiman tribe of the Karakalpaks. It turns out that Tekelik belongs to Andijan region. The spinner belongs to the Chinese tank group. It is divided into red, yellow, ankle, foot, ankle and crow's feet.

At the time of the 1926 census, there were 1,305 Karakalpaks in Fergana, 170 in Zarafshan, 290 in Samarkand, 137 in Tashkent, 1,4043 in Andijan, 5,938 in Kenimekh, and 1,537 in Turkmenistan.

In fact, at the present time in the Altyaryk, Taslak districts of Fergana, Pap, Torekorgan, Zadarya, Chimkorgan, Kasansai, Uishi districts of Namangan, Pakhtaabad, Balykshi, Altynkol Izbaskan, Andijan, Chinabad, Khojabad districts of Andijan. There were three or four captives who were separated from our people. Therefore, it is natural for their 
CURRENT RESEARCH JOURNAL OF PHILOLOGICAL SCIENCES 2(11):

72-79, November 2021

DOI: https://doi.org/10.37547/philological-crjps-02-11-17

ISSN 2767-3758

(C)2021 Master Journals

\section{Crossref do:}

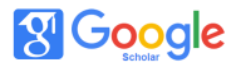

Accepted $25^{\text {th }}$ November, 2021 \& Published $30^{\text {th }}$ November, 2021

language to be different.

However, the older generation of Fergana Karakalpaks thinks that they speak Karakalpak. In the phonetics of the language of older people, the speech with the letter " $\mathrm{j}$ " is in the form of weeping or not, as well as the rule of synharmanism.

Here are the names of the traditions of the Fergana Karakalpaks:

Those who ask for a bridesmaid from their house, ask the shanarak whether they are going to a bridesmaid. Today, the bride is chosen by the groom, but this was not the case in the 70s and 80s. The bride was chosen by the elders of the house. The girl's house was going to go hunting after getting used to her family.

Nobody went hunting. Elders, dignitaries, and eloquent people were sent to that village. The bridegroom was well received (even if he did not intend to give her away). The soldiers were treated to some food. Mostly expected with pilaf and soup. He went hunting two or three times.

Dressed in white - if the girl agrees, the bridesmaids are given white goods, white soup, a white scarf, and a white dress. This tradition is called "white dress". This meant that the couple was divorced. The bride and groom were not seen by their fatherin-law or mother-in-law. The ceremony was attended by 4 women. The bride was brought to the shanarak.

For those who came with the next four types of sarpai, a dress, a scarf should be white, and a mask was brought. The basket came with bread, nabat, white sugar, tea, mutton, rice pilaf and soup. First, boiled soup and then pilaf were served. The girl went to the groom's house that day with a basket, flats and soms in the basket. This is called "kuda tusti" in Karakalpak Karakalpaks. But Fergana differs from the traditions of the Karakalpaks.

In the meantime, the bride and groom held a "blanket hashar" ceremony to make a blanket bed. This was desired by the agreement of the two gods. For example, on the bride's side, representatives of the groom's side came and brought cotton, mutton and rice to put on the blanket. In addition, there are women of all ages, about 30-40, with needles, socks and blankets.

The date of the wedding is set by agreement of the two parties. The day before, the groom left the bride's house with a lamb, pilaf and soup. On the girl's side, a sheep is slaughtered and prepared. In other cases, the items to be placed in the tradition were carried by the in-laws on the day of the wedding. The godparents consisted of at least 20 people, male and female relatives. 30-40 people were waiting for the bridesmaids. The first person I met with the godparents put white flour on their foreheads. The latter gave sweets to the in-laws. The entrance to the wells was paved with a sledgehammer (the sledgehammer was made of flax and ammunition). The wells were seated and incense burned, and then water was poured into the hands.

Opening of the garden - After the feast, the bride's bag (bag) is opened. The one who opens the garden is given a piece of clothing. At least eight types of handkerchiefs, winter clothes and scarves were brought to the bride in the garden. In the Karakalpaks of the Republic of Karakalpakstan, this tradition is called "traditional opening".

Wedding Dressing - At the end of the feast there will be a wedding dressing ceremony. Now the bride is dressed in a robe for each of the guests, a coat for men, a belt for women, a dress for women and a scarf for the bride. 
CURRENT RESEARCH JOURNAL OF PHILOLOGICAL SCIENCES 2(11):

72-79, November 2021

DOI: https://doi.org/10.37547/philological-crjps-02-11-17

ISSN 2767-3758

(C)2021 Master Journals

Crossref doi

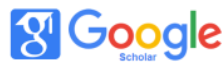

Accepted25th November, 2021 \& Published 30 ${ }^{\text {th }}$ November, 2021

The vessel is back - The ceremony of "return of the vessel" was held in consultation with the two brothers. The ceremony was attended by about ten women, all of whom were women. This ceremony is not common in Karakalpaks.

The bride has run away - she will not be at the bride's house on the wedding day, she will stay at the house of her neighbor or friend. This tradition is called "the bride ran away". However, in the Republic of Karakalpakstan, the term does not apply to Karakalpaks.

When the bridegroom came to the house, he showed it to the bridegroom's relatives and greeted him. This tradition is called "face over". It is used in Karakalpaks in the Republic of Karakalpakstan under the term "bet ashar". In our lexicon, the words face (hundred) are synonymous.

Kormana-Kelinshek was given a "kormana" after his relatives saw him. Kormana was provided with household items and utensils. He was also involved in the making of household utensils. The bride's mother gave a tradition to the "kormana". All these items were necessary for their household. The name of these traditions in the Republic of Karakalpakstan is called "Korimlik" in Karakalpaks.

The bride is not sitting - when the bride came to the groom's house, she put him on the curtain. The curtain was made by the groom's mother. There was a rule to hold the curtain. The mother of the bridegroom tied a white scarf on one of the curtains and the mother of the bride tied a scarf on the other. After the bride was put on the curtain, the bride's friends shouted, "The bride is not sitting." Then the bride's mother-in-law, or an older woman, comes out and says, "I'll do everything," and the bride sits down. (Narrator Userbay Mamatov, born in 1941. Karakalpak Kipchak tribe.)
Feedback: The materials we have collected in the village of Tekeli, Yazyavan district, can be heard in the language of the Karakalpaks in the language of older people: It is also noticeable that words such as жер, жейсенми, жылама, журсак ма appear at the beginning of the word in Uzbek instead of the sound "й". Our people would like "j" more (Takalik village). Due to the crises of different epochs, our people have moved in all directions. Each tribe moved to a place that suited them. It was made in those places. Their language and culture were influenced by the center they created.

\section{Conclusion}

We have already seen the terms associated with Karakalpak customs, which are made outside of Karakalpakstan, that is, in the Kenimek district of Navoi region and in the Yazyavan district of Fergana region. The Karakalpaks of Kenimek district opened Karakalpak schools due to their regional proximity to Karakalpakstan and their cultural ties. They are now receiving education in their mother tongue. The language of the Kenimekli Karakalpaks was studied in science as the Kenimek dialect of the Karakalpak language. And the language of the Karakalpaks of Fergana D.Nasyrov in his works called "Isolated speech". Three or four of them were separated from our people. Due to the lack of communication in the language of the Fergana Karakalpaks, it is natural that the media do not receive education in their mother tongue in schools due to the lack of communication, radio, television, newspapers and magazines, ie cultural ties. However, the differences in the languages of the Upper Karakalpaks gave rise to a colorful ethnolexicon. In short, language is a belief given to us by Mother Nature, and therefore the study of local language differences is one of the most important tasks of linguistics. By collecting valuable materials from the regions of the Upper Karakalpaks, studying their linguistic differences, comparative 
CURRENT RESEARCH JOURNAL OF PHILOLOGICAL SCIENCES 2(11):

72-79, November 2021

DOI: https://doi.org/10.37547/philological-crjps-02-11-17

ISSN 2767-3758

(C)2021 Master Journals

crossref do) 8: Google

Accepted25 $5^{\text {th }}$ November, 2021 \& Published 30th November, 2021

study of the modern Karakalpak literary language and dialect, as well as the neighboring Uzbek, Kazakh and Kyrgyz languages, to show their linguistic differences, we think that is one of the most pressing issues.

The dialects and dialects of the Turkic languages have been extensively studied. However, the dialectal differences of the Karakalpak language have not been fully studied. Dialects were left out of the study. Therefore, this issue is one of the most pressing issues in Karakalpak dialectology.

\section{REFERENCES}

1. New history of Karakalpakstan. Nökis, Karakalpakstan Publishing House, 2003, 10 pages, 554 pages.

2. Davydov A. Public building of the Golden Horde. Moscow, 1973, p. 102.

3. Камалов С. From the formation of the Karakalpaks as a people and the history of its statehood. Nukus, Journal of the EBRD "Bulletin", 2001, 23 pages.

4. D.Nasyrov. The formation of the Karakalpak common colloquial language and its dialect system. Karakalpakstan, Nukus-Kazan, 1976, p. 288.

5. Prekeeva A. "Kenimekli Karakalpak style". Candidate of Philological Sciences diss. ... author's ref., Nukus, 2012, 19 pages.

6. Nasyrov D, Dospanov O. Dialectological dictionary of the Karakalpak language. Nukus: Karakalpakstan, 1983, 285 pages.

7. Karimov A., Pakhratdinov A., Nietullaev S. New information about Upper Karakalpaks. From materials of 1958 // Amiudarya, Nukus, 1959, №4, 91 pages.

8. Explanatory dictionary of the Karakalpak language. Nukus: Karakalpakstan, 1988, Vol. III, 294 pages.

9. Nasyrov D., Dospanov O. Dialectological dictionary of the Karakalpak language. Nukus:

\section{Karakalpakstan, 1983, 289 pages.}

10. Shinnazarova S. Peculiarities of the Karakalpak language in the Kanlykol region of Karakalpakstan. Philol. science. candid. diss. ... author's ref., Nukus, 2009, 12 pages. 